\title{
Article \\ Effect of Urban-Rural Income Gap on the Population Peri-Urbanization Rate in China
}

\author{
Bingyang Han ${ }^{1}{ }^{(D}$, Zhili Ma ${ }^{1, *}$, Yong Liu ${ }^{1}$, Mengmeng Wang ${ }^{1}$ and Yingchao Lin ${ }^{2}$ \\ 1 School of Management Science and Real Estate, Chongqing University, Chongqing 400045, China; \\ hanbingyang@cqu.edu.cn (B.H.); liuyong80@cqu.edu.cn (Y.L.); mengmengwang@cqu.edu.cn (M.W.) \\ 2 School of Public Affairs, Zhejiang University, Hangzhou 310058, China; linyc@zju.edu.cn \\ * Correspondence: mzlmx@cqu.edu.cn
}

check for updates

Citation: Han, B.; Ma, Z.; Liu, Y.; Wang, M.; Lin, Y. Effect of

Urban-Rural Income Gap on the Population Peri-Urbanization Rate in China. Land 2021, 10, 1255. https:// doi.org/10.3390/land10111255

Academic Editor: Alexandru-Ionuţ Petrişor

Received: 7 October 2021

Accepted: 13 November 2021

Published: 17 November 2021

Publisher's Note: MDPI stays neutral with regard to jurisdictional claims in published maps and institutional affiliations.

Copyright: (c) 2021 by the authors. Licensee MDPI, Basel, Switzerland. This article is an open access article distributed under the terms and conditions of the Creative Commons Attribution (CC BY) license (https:// creativecommons.org/licenses/by/ $4.0 /)$.

\begin{abstract}
Attracted by the urban-rural income gap (URIG), a massive agricultural transfer population has flooded into cities and became a peri-urbanized population due to the restrictions of the household registration system. This trend eventually leads to the rising population peri-urbanization rate (PPUR), which is equal to the proportion of urban resident population with rural household registration in the total residents, and seriously affects the development of new-type people-oriented urbanization. The purpose of this study is to investigate the impact of URIG on PPUR at the national and regional levels using the spatial exploration analysis and spatial Durbin model from the perspective of comparative economic interests. Empirical results revealed that PPUR had high spatial agglomeration, as indicated by high values in Eastern China and low values in Central and Western China. Moreover, the PPUR of most provinces in China was rising, dominated by intermediate values. At the national level, URIG promoted the increase of PPUR in the province, but inhibited the increase of PPUR in nearby provinces. Except for household registration, other control variables, such as industrial structure, fixed asset formation rate, infrastructure, medical resources and land-centered urbanization, also contributed to the PPUR in the province. At the regional level, the URIG of Central and Western China contributed to the increase of PPUR, whereas in Eastern China it inhibited the increase of PPUR. The strong correlation of URIG and PPUR calls for relevant policies for narrowing URIG and reducing PPUR.
\end{abstract}

Keywords: population peri-urbanization rate; urban-rural income gap; household registration system; spatial econometrics

\section{Introduction}

In 2019, China's urbanization rate of permanent population reached $60.60 \%$, whereas its urbanization rate of household registration population accounted for only $44.38 \%$ [1], indicating a great population peri-urbanization rate (PPUR) of $16.22 \%$. Nearly $200-300$ million agricultural transfer populations (ATPs) floated between urban and rural areas, resulting in the annual migration tide. Apart from the household registration system, the existence of high housing prices and social security system in large cities hinder the in situ urbanization of these ATPs [2,3]. As Saunders [4] commented in 'Arrival City', the 21st century will probably be the last great migration wave of mankind. The problem of urban-rural migration remains unsolved and may cause huge social unrest in the near future. Consequently, China released the National New-type Urbanization Plan (2014-2020), which emphasized the transformation from land-centered urbanization to people-centered urbanization $[5,6]$ and planned to improve the urbanization rate of household registration population by approximately $1.2 \%$ annually. To achieve this goal, an in-depth study should be devoted to the issue of PPUR and its mechanism and influencing factors.

According to national characteristics, peri-urbanization is mainly divided into land peri-urbanization (geography, land dimension) and population peri-urbanization (demography, institutional dimension). Land peri-urbanization was first studied by scholars. Peri- 
urbanization in geography was originally pointed out by Gottmann [7] in the metropolitan band theory. Thereafter, McGee [8] proposed the concept of 'Desakota', which refers to the 'peri-urbanization area' distributed in the urban fringe, extended metropolitan area, and urban-rural integration. In developing countries, peri-urbanized areas are actually urban-rural mixed transitional areas located on the periphery of cities [9]. The term periurbanization is known as a process in which rural areas located in the suburbs of built-up cities have become urbanized not only in the external landscape, but also in the economic structure and social fabric [10]. Webster [11] defined the peri-urbanization of East Asia from a dynamic perspective, where in this region, the number of employees in manufacturing and the number of employees in the primary sector (agriculture, fisheries) both account for more than $20 \%$ of the labor force. However, the proportion of the former is increasing and the proportion of the latter is decreasing. Moreover, Webster et al. [12] held that China's peri-urban areas are entering the third stage of peri-urbanization, in which the human resources in mature enterprises continue to shift to more productive roles, rather than simply an influx of immigrants. Zhu and $\mathrm{Hu}$ [13] classified the uncoordinated land non-agriculturalization and disorderly material development in the peri-urban areas as a peri-urbanization model. Tian [14] pointed out that the expansion of China's peri-urbanized areas is driven by both land finance and agricultural industrialization. Furthermore, Tian et al. [15] deemed that the remarkable characteristics of China's periurbanization are the sharp decline of cultivated land and forest land and the rapid increase of industrial land.

The issue of demographic peri-urbanization is more prominent in China than other countries featured by geographical peri-urbanization. Wang [16] first proposed that population peri-urbanization is a state of unconformity in the process of urbanization. Population peri-urbanization can be regarded as a special production of the Chinese household registration system (CHRS), which restricts the permanent settlement of ATP in cities [3]. Although ATP has achieved geographical transfer and occupation transformation, it cannot realize the change of identity and status and enjoy the basic public services. In addition, some scholars have proposed that China's PPUR is expected to follow an inverted Ushaped evolution pattern [3]. Generally speaking, peri-urbanization refers to this type of region, with the reduction of agricultural land and the increase of industrial land. This kind of peri-urbanization is defined geographically as land peri-urbanization, in which non-agricultural activities are carried out in an urban-rural fringe zone, especially in urban suburbs. This study focuses on population peri-urbanization. Specifically, compared with urban residents with non-agricultural hukou, although ATPs work and live in the city, they have not fully realized urbanization in the dimensions of identity recognition, urban belonging, and welfare benefits due to holding agricultural hukou.

To further realize people-oriented urbanization, scholars have conducted extensive research on the influencing factors of PPUR. Some scholars have argued that land finance significantly promotes PPUR, and the efficiency of public service supply evidently retards the speed of PPUR on the basis of county-level data [2]. Certainly, the increase of periurbanized population may be closely related to foreign direct investment $[17,18]$. Other studies have shown that the household registration system determines the breadth and depth of peri-urbanization by affecting population mobility. Many scholars have deemed that the reduction of land supply contributes to the rising housing prices, which, in turn, boost PPUR. The flow of ATP is restricted by factors such as the household registration system, urban-biased public policies, and rural land systems, all of which have been proven to be important reasons for peri-urbanization [19]. A few studies have found that the increase of farmers' income level significantly promotes PPUR in this region, but has a negative spatial spillover effect on neighboring areas [20].

However, only few studies have investigated the impact of urban-rural income gap (URIG) on PPUR. First, urbanization includes multiple dimensions, such as population urbanization, economic urbanization, land urbanization, and social urbanization [21]. Liu et al. [3] pointed out that peri-urbanization may be one stage of urbanization in the 
Chinese society. In addition, URIG is the Granger cause of urbanization [22]. URIG may have some impact on the population urbanization rate, which must urgently be investigated. Second, some empirical studies have revealed a significant positive correlation between PPUR and the disposable income of urban residents. Third, according to the Todaro migration model, as long as expected positive URIG exists, the trend of rural labor migration from rural to urban areas will continue, which may promote the increase of PPUR [23].

At present, two prominent issues arise in the research on the influencing factors of PPUR. On the one hand, relatively few studies have been devoted to explore the impact of URIG on PPUR from the perspective of income disparity. On the other hand, previous works have mostly used research methods, such as ordinary panel regression and time series regression, which ignore the inter-provincial population flow and thus, may have estimation bias. To fill the gap, the present study attempts to investigate the impact of URIG on PPUR from 2005 to 2014 using the spatial Durbin model (SDM) to effectively reduce the estimation bias. Furthermore, this research on the impact of URIG on PPUR can provide references for developing countries that adopt the household registration system.

\section{Materials and Methods}

\subsection{Materials}

\subsubsection{Research Framework and Study Area}

The research framework of this study is shown in Figure 1. The study area included 31 provinces, municipalities, and autonomous regions in China, excluding Hong Kong, Macao, and Taiwan. The study area covered three regions, namely, Eastern, Central, and Western China, as shown in Figure $2[20,24]$.

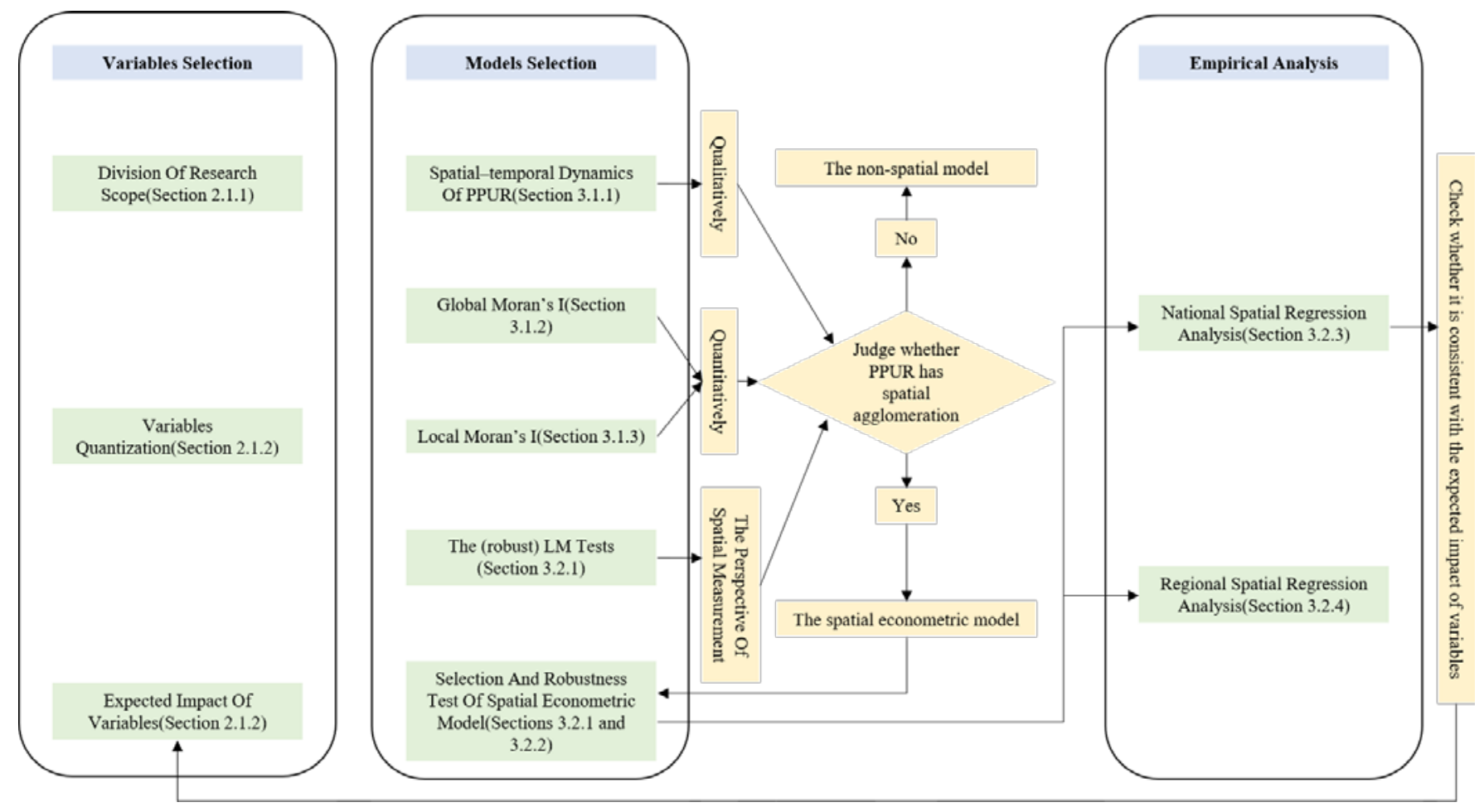

Figure 1. Research framework. 


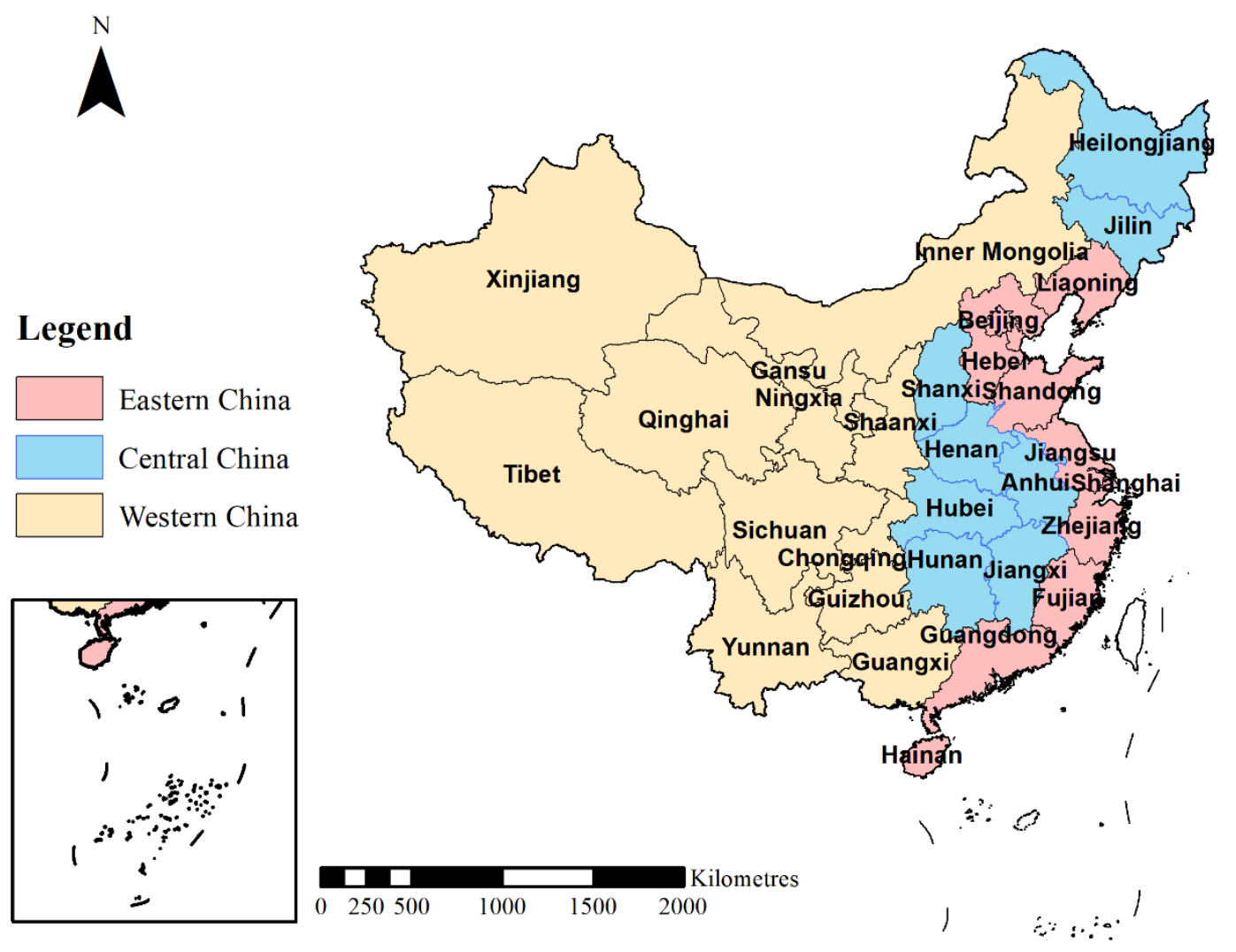

Figure 2. Research scope.

\subsubsection{Variable Selection}

The term 'peri-urbanization' is defined geographically and demographically as land peri-urbanization and population peri-urbanization. Land peri-urbanization refers to the urbanization model of the transition of land use, industrial structure, and landscape features from rural to urban. However, population peri-urbanization is defined in the context of the household registration system. The peri-urbanization of the population indicates that ATPs (i.e., peri-urbanized population with agricultural hukou) have a significant gap with the urban household registration population (with non-agricultural hukou) in terms of identification, urban belonging, and welfare benefits. Take China as an example, where the household registration system is adopted. The total urban and rural population consists of urban household registration population and rural household registration population. The peri-urbanized population should meet two conditions at the same time: (1) Live in cities and towns for more than 6 months in a year; (2) have no urban household registration. Moreover, the second condition shows that the peri-urbanized population excludes the members who come from other cities, but have non-agricultural hukou. Furthermore, these members from other cities, but with non-agricultural hukou, are actually considered to be the frequent floating population with local urban household registration. According to official statistics, the urban permanent population consists of the floating population and the local urban household registration population. Generally speaking, the urbanization rate is equal to the ratio of the urban permanent population to the total urban and rural population, which is also called the urbanization rate of permanent population (URPP). However, the peri-urbanized population included in the urban permanent population enjoys a differential treatment in terms of social welfare benefits and has not fully realized urbanization. In addition, this study focuses on the proportion of the ATPs (i.e., periurbanized population) in the total urban and rural population, which is the population peri-urbanization rate (PPUR). However, official statistics do not provide data on population movements with non-agricultural hukou in each province (which is the frequent 
floating population with local urban household registration), but only general statistics on the local urban household registration population. Therefore, it will be difficult to calculate the population peri-urbanization rate in strict accordance with the definition of peri-urbanized population, especially when it involves collecting data from several years ago. Given the availability of data, the study uses the difference between the urban permanent population and the local urban household registration population to calculate the peri-urbanized population of each province. This method will have more serious deviations when the frequent floating population with local urban household registration is larger. However, in view of the fact that there are a certain number of the frequent floating population with local urban household registration and the inflowing population with urban household registration of other cities, this deviation can be offset in a certain sense from a national perspective. In summary, the study adopts the peri-urbanized population to be approximately equal to the urban permanent population minus the local urban household registration population. The ratio of the local urban household registration population to the total urban and rural population is regarded as the urbanization rate of household registration population (URHRP). In other words, PPUR is equivalent to URPP minus URHRP $[20,25]$.

The Todaro migration model explains the rational economic behavior of ATP from rural to urban areas driven by comparative economic benefits in China [23]. The model only compares the transfer cost and expected income, it does not consider the living cost of ATP in cities. However, the most concerned problems for ATP in cities are nothing more than employment and life. The primary driving force for the continuous transfer of ATP from rural to urban areas is URIG. Therefore, this study uses URIG as the core explanatory variable, and measures it by the ratio of per capita disposable income of urban households to per capita net income of rural households. The per capita disposable income of urban households is calculated based on the disposable income of urban households (disposable income of urban households = total household income-income tax-personal contribution to social security-subsidy for keeping diaries for a sampled household). The per capita net income of rural households is calculated based on the net income of rural households (net income of rural households = total income-household operation expenses-taxes and fees-depreciation of fixed assets for production-gifts to rural relatives).

Numerous studies have been committed to differentiating the influencing factors of urbanization, which include economic levels, fixed asset investment, transportation construction, personal income, public services, and other determinants $[2,26,27]$. The efficiency of public services significantly retards the velocity of peri-urbanization. However, the household registration difference and economic bias aggravate this process. Therefore, this research further investigates the influence of URIG on PPUR by selecting control variables from the following six dimensions: Industrial structure (NS), fixed asset formation rate (AF), infrastructure (FS), medical resources (MR), household registration $(\mathrm{HJ})$, and land-centered urbanization (LAND). The variables are summarized in Table 1.

Table 1. Description and calculation of variables.

\begin{tabular}{cccc}
\hline Variables & Descriptions & Definitions & Data Sources \\
Influence
\end{tabular}


Table 1. Cont.

\begin{tabular}{|c|c|c|c|c|}
\hline Variables & Descriptions & Definitions & Data Sources & $\begin{array}{l}\text { Expected } \\
\text { Influence }\end{array}$ \\
\hline URIG & $\begin{array}{l}\text { An indicator to measure the income } \\
\text { gap between urban and rural areas }\end{array}$ & $\begin{array}{l}\text { per capita disposable income of urban } \\
\text { households/per capita net income of } \\
\text { rural households }\end{array}$ & $\begin{array}{l}\text { China Statistical } \\
\text { Yearbook }\end{array}$ & positive \\
\hline NS & $\begin{array}{l}\text { An indicator that indicates the } \\
\text { proportion of the industrial structure } \\
\text { of a region }\end{array}$ & $\begin{array}{l}\text { the output values of the secondary } \\
\text { and tertiary industries/GDP }\end{array}$ & $\begin{array}{l}\text { China Statistical } \\
\text { Yearbook }\end{array}$ & positive \\
\hline $\mathrm{AF}$ & $\begin{array}{c}\text { An indicator to measure job } \\
\text { opportunities }\end{array}$ & the total fixed capital formation/GDP & $\begin{array}{l}\text { China Statistical } \\
\text { Yearbook }\end{array}$ & positive \\
\hline FS & $\begin{array}{l}\text { An indicator to measure the carrying } \\
\text { capacity of the city }\end{array}$ & per capita municipal road area & $\begin{array}{l}\text { China Statistical } \\
\text { Yearbook }\end{array}$ & positive \\
\hline MR & $\begin{array}{c}\text { An indicator to measure the cost of } \\
\text { living }\end{array}$ & $\begin{array}{l}\text { the number of beds per } \\
1000 \text { population medical institutions }\end{array}$ & $\begin{array}{l}\text { China Statistical } \\
\text { Yearbook }\end{array}$ & positive \\
\hline $\mathrm{HJ}$ & $\begin{array}{c}\text { An indicator to measure the degree of } \\
\text { control of household registration } \\
\text { system }\end{array}$ & $\begin{array}{l}\text { the city's annual change of naturalized } \\
\text { population/the number of new } \\
\text { subscribers of mobile telephones }\end{array}$ & $\begin{array}{c}\text { China City } \\
\text { Statistical Yearbook }\end{array}$ & negative \\
\hline LAND & $\begin{array}{c}\text { An indicator to measure the level of } \\
\text { land urbanization }\end{array}$ & $\begin{array}{c}\text { built-up area of municipal } \\
\text { district/area of municipal district }\end{array}$ & $\begin{array}{c}\text { China City } \\
\text { Statistical Yearbook }\end{array}$ & positive \\
\hline
\end{tabular}

Notes: * represents the operation symbol of multiplication. Missing values are supplemented from the Statistics Bulletin of National Economic and Social Development.

\subsubsection{Variable Descriptive Statistics}

The research time span is from 2005 to 2014. The reason for this selection is due to the fact that the statistic caliber of urban resident population began in 2005, whereas the number of local urban household registration population announced in the 'China Population and Employment Statistics Yearbook' was suspended in 2014. In general, variables must be logarithmically processed to eliminate the influence of heteroscedasticity and outliers on the model to the greatest extent. However, this study keeps the variables as original data for three reasons: Individual variables are negative; nearly half of the variables range from 0 to 1 ; the raw data can directly explain the economic significance amongst variables. The descriptive statistics of variables of 31 provinces, municipalities, and autonomous regions of China in 2005-2014 are presented in Table 2.

Table 2. Variable descriptive statistics.

\begin{tabular}{|c|c|c|c|c|c|c|}
\hline Variable & Unit & Obs & Mean & Std. Dev. & Min & Max \\
\hline PPUR & $\%$ & 310 & 13.004 & 6.961 & -5.590 & 32.350 \\
\hline URIG & - & 310 & 2.990 & 0.578 & 1.852 & 4.594 \\
\hline NS & - & 310 & 0.884 & 0.058 & 0.664 & 0.995 \\
\hline $\mathrm{AF}$ & - & 310 & 0.643 & 0.197 & 0.093 & 1.242 \\
\hline FS & $\mathrm{m}^{2} /$ person & 310 & 12.795 & 4.019 & 4.040 & 25.770 \\
\hline MR & $\begin{array}{l}\text { beds/per } \\
1000 \text { people }\end{array}$ & 310 & 3.662 & 0.953 & 1.651 & 6.221 \\
\hline $\mathrm{HJ}$ & - & 310 & 1.137 & 8.143 & 0.001 & 97 \\
\hline LAND & - & 310 & 0.067 & 0.050 & 0.005 & 0.271 \\
\hline
\end{tabular}

\subsection{Methods}

If PPUR has spatial agglomeration, then the spatial econometric model can be used rather than the non-spatial model. Whether the spatial econometric model can be introduced can be verified not only through exploratory data analysis, but also through (robust) LM tests. Exploratory data analysis not only includes judging whether PPUR has agglomeration characteristics intuitively from the spatial-temporal transformation map, but also utilizing Global Moran's I and Local Moran's I to confirm the existence of spatial 
relationships quantitatively. Global Moran's I and Local Moran's I of PPUR are calculated by the geographic distance matrix.

\subsubsection{Global Moran's I}

Global Moran's I is a commonly used global spatial autocorrelation statistic, which describes the average correlation and significance of observational variables amongst all of the spatial units throughout the study area, namely:

$$
\mathrm{I}=\frac{\mathrm{n} \sum_{\mathrm{i}=1}^{\mathrm{n}} \sum_{\mathrm{j}=1}^{\mathrm{n}} \mathrm{w}_{\mathrm{ij}}\left(\mathrm{x}_{\mathrm{i}}-\overline{\mathrm{x}}\right)\left(\mathrm{x}_{\mathrm{j}}-\overline{\mathrm{x}}\right)}{\left(\sum_{\mathrm{i}=1}^{\mathrm{n}} \sum_{\mathrm{j}=1}^{\mathrm{n}} \mathrm{w}_{\mathrm{ij}}\right) \sum_{\mathrm{i}=1}^{\mathrm{n}}\left(\mathrm{x}_{\mathrm{i}}-\overline{\mathrm{x}}\right)^{2}},
$$

where $\mathrm{w}_{\mathrm{ij}}$ is the weight matrix between spatial unit $\mathrm{i}$ and $\mathrm{j}$, which is usually standardized by rows; $\bar{x}=\frac{1}{n} \sum_{i=1}^{n} x_{i}$, where $x_{i}$ represents the observation of spatial unit $i$; and $n$ is the number of space units, which refers to 31 provinces, municipalities, and autonomous regions.

Global Moran's I is valued in the range of $[-1,1]$. The closer I is to 1 , the stronger the positive spatial correlation amongst the regions is; the closer I is to -1 , the stronger the negative spatial correlation; and I equals 0 , indicating that no spatial correlation exists, in which the observations are randomly distributed as a whole.

\subsubsection{Local Moran's I}

The local spatial autocorrelation statistic is used to describe the local distribution state of a single spatial unit to observe the local instability and spatial heterogeneity of data. The formula is as follows:

$$
I=\sum_{j=1}^{n} \frac{w_{i j}\left(x_{i}-\bar{x}\right)\left(x_{j}-\bar{x}\right)}{\sigma^{2}},
$$

where $\sigma^{2}$ is the variance of $x$, and the meaning of the other variables is the same as Formula (1).

\subsubsection{Spatial Weight Matrix}

The spatial weight matrix, which mainly includes geographic adjacency matrix, geographic distance matrix, and economic distance matrix, reflects spatial dependence amongst sample observations, which must be specified in advance when conducting the spatial econometric analysis. Considering that the primary consideration for ATP is URIG and geographical distance, the economic distance weight calculated by Formula (5) is used in subsequent models. To ensure the robustness of estimation results, the model using different matrices is analyzed in the empirical analysis [28].

Adjacent matrices are divided into first-order, second-order, and multi-level weight matrices. In this study, the simplest first-order adjacent matrix, queen adjacent matrix, is adopted, namely:

$$
W_{i j}=\left\{\begin{array}{l}
1, \text { if unit } i \text { and unit } j \text { have common edges or apexes } \\
0, \text { otherwise. }
\end{array}\right.
$$

The geographical adjacency matrix only considers the influence between adjacent elements, but cannot distinguish the influence difference of different adjacent units. However, the geographic distance matrix incorporates the attenuation effect of distance, and the farther apart the two spatial units are, the weaker the spatial correlation is. The geographical distance matrix in this study is based on the longitude and latitude of the two provinces to calculate spherical distance ' $\mathrm{d}_{\mathrm{ij}}$ ', and then take the reciprocal of distance square, which is expressed as:

$$
W_{i j}=\left\{\begin{array}{r}
1 /\left(d_{i j}\right)^{2}, i \neq j \\
0, i=j
\end{array} .\right.
$$


Although the geographical distance matrix considers the differences of spatial influence amongst different units, the main factors affecting the migration of ATP may be the economy, rather than the geographical distance, given the current convenient transportation situation. Provinces with a strong economy likely trade with other provinces, and geographical barriers cannot resist the attractiveness of more employment opportunities and higher income to ATP. Considering that the per capita gross domestic product (GDP) can laterally reflect the economic level of a region, the study uses the per capita GDP to construct the economic distance weight under the premise of retaining the reciprocal of distance square. The expression is shown in Equation (5). ' $\mathrm{M}_{\mathrm{i}}{ }^{\prime}$ represents the per capita GDP of space unit $\mathrm{i}$ in 2014.

$$
\mathrm{W}_{\mathrm{ij}}=\left\{\begin{array}{r}
\left(1 /\left(\mathrm{d}_{\mathrm{ij}}\right)^{2}\right) *\left(1 /\left|\mathrm{M}_{\mathrm{i}}-\mathrm{M}_{\mathrm{j}}\right|\right), \mathrm{i} \neq \mathrm{j} \\
0, \mathrm{i}=\mathrm{j}
\end{array} .\right.
$$

\subsubsection{Spatial Econometric Models}

In general, spatial econometric models are composed of three kinds: The spatial lag model (SLM) with a spatially lagged dependent variable, the spatial error model (SEM), which incorporates the spatial autoregressive process into the error term [29], and SDM with a spatially lagged dependent variable and spatially lagged independent variable, which can be converted into the above two models under certain conditions [30], as follows:

$$
\begin{gathered}
\text { SLM }: y_{i t}=\rho \sum_{j=1}^{N} W_{i j} y_{j t}+X_{i t} \beta+c_{i}+\mu_{t}+\varepsilon_{i t} \\
\text { SEM : } y_{i t}=X_{i t} \beta+c_{i}+\mu_{t}+\varphi_{i t}, \varphi_{i t}=\gamma \sum_{j=1}^{N} W_{i j} \varphi_{j t}+\varepsilon_{i t} \\
\text { SDM }: y_{i t}=\rho \sum_{j=1}^{N} W_{i j} y_{j t}+X_{i t} \beta+\sum_{j=1}^{N} W_{i j} X_{j t} \theta+c_{i}+\mu_{t}+\varepsilon_{i t},
\end{gathered}
$$

where $y_{i t}$ represents the dependent variable of section $i$ at time $t(i=1, \ldots, N ; t=1, \ldots$, $\mathrm{T}) ; \sum_{\mathrm{j}} \mathrm{W}_{\mathrm{ij}} \mathrm{y}_{\mathrm{jt}}$ symbolizes the interrelationships of $\mathrm{y}_{\mathrm{it}}$ with the $\mathrm{y}_{\mathrm{jt}}$ of adjacent elements, of which $W_{\mathrm{ij}}$ expresses a predestined nonnegative n-dimensional spatial weight matrix with row I and column J elements; endogenous row vector $X_{i t}$ is the $K$ dimension, whereas $\beta$, $\theta$ denote a $K \times 1$ vector of fixed, but unknown parameters; $\rho$ and $\gamma$ refer to the spatial autoregressive coefficient and spatial autocorrelation coefficient, respectively. In addition, $c_{i}$ indicates spatial fixed effects and $\mu_{t}$ refers to time fixed effects. Moreover, $\varphi_{i t}$ is the error term of spatial autocorrelation, whereas $\varepsilon_{\mathrm{it}}$ is an independently and identically distributed error term with zero mean and variance $\sigma^{2}$.

To test whether SLM or SEM is more suitable for describing data than the model without any spatial interaction effects, (robust) LM tests can be conducted. These two tests are based on the residuals of non-spatial models with or without spatial and/or time fixed effects. Given that the results of robust LM tests vary due to different effects [29], this study estimates four models with four effects using MATLAB R2019a software. If the (robust) LM tests pass, then the conclusion is that choosing SLM or SEM is reasonable. Contrarily, the non-spatial model is adopted [29]. Subsequently, based on the LR-test joint significance, we can determine whether the spatial model has spatial and/or time fixed effects.

Moreover, Lesage and Pace [30] suggested that SDM should be considered. Hypotheses 1 and 2 are as follows: Hypothesis 1 can be used to test whether SDM can be simplified into SLM; Hypothesis 2 can be used to examine whether SDM can be simplified into SEM. These hypotheses can be validated in the form of a likelihood ratio (LR) test, provided that SLM and SEM have been estimated. Contrarily, these hypotheses can only be made in the form of a Wald test.

Hypothesis 1: Assume that $\theta$ is equal to 0.

Hypothesis 2: Assume that $\theta$ is equal to ' $-\rho \beta$ '. 
If the (robust) LM tests point to SLM and Hypothesis 1 cannot be rejected, then SLM best describes the data. Similarly, if the (robust) LM tests point to SEM and Hypothesis 2 cannot be rejected, then SEM best describes the data. Undoubtedly, if the two conditions cannot be simultaneously satisfied, in which the model pointed by the (robust) LM tests is different from the LR/Wald test, then SDM should be used. The reason is that SDM is the generalization of SLM and SEM. Evidently, if these hypotheses are rejected, then SDM should also be adopted. Finally, after determining which spatial econometric model to choose, the Hausman test is conducted to determine whether the model should include fixed effects or random effects.

\section{Results}

\subsection{Exploratory Data Analysis}

\subsubsection{Spatial-Temporal Dynamics of PPUR}

To visually observe the spatial-temporal changes of PPUR in China, the research di-vides the data in 2005, 2007, 2010, 2012, and 2014 into four segments, which are shown by ArcGIS10.2 software in Figure 3. In Figure 3, the study intuitively assumes that PPUR has spatial agglomeration, and the influence of URIG on PPUR is heterogeneous amongst regions. From 2005 to 2014, the number of provinces with the highest-degree PPUR and a higher-degree PPUR increased, and the number of provinces with a lower-degree PPUR and the lowest-degree PPUR decreased. Overall, many provinces with higher- and lower-degree PPUR were recorded. In terms of spatial distribution, the highest-degree PPUR spread from the southeast coastal areas to the surrounding areas; the higher-degree from the south to the north; the western region and the three northeastern provinces gradually developed from the lowest-degree to a lower-degree. Specifically, the provinces with the highestdegree PPUR were mainly Zhejiang, Fujian, Hunan, and Anhui, whereas the provinces with the lowest-degree PPUR were Xinjiang and Tibet. The PPUR of Beijing, Shanghai, and Jiangsu in Eastern China was decreasing, and the PPUR of Shanghai was eventually negative. Moreover, the PPUR of Chongqing and Qinghai in Central and Western China was on a downward trend. Nevertheless, the PPUR showed the characteristics of high values in Eastern China and low values in Central and Western China, and the PPUR of most provinces was on the rise.

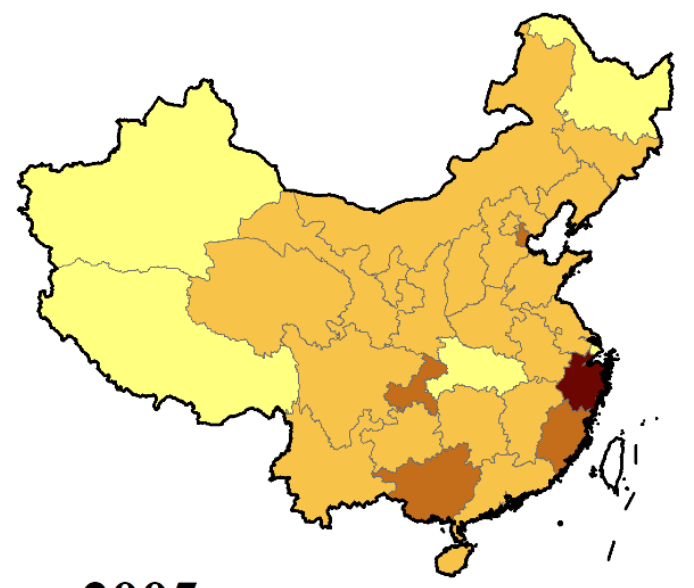

2005

$$
\begin{aligned}
& 1: 0.1 \\
& 1,1 \\
& 1, \cdots=1
\end{aligned}
$$

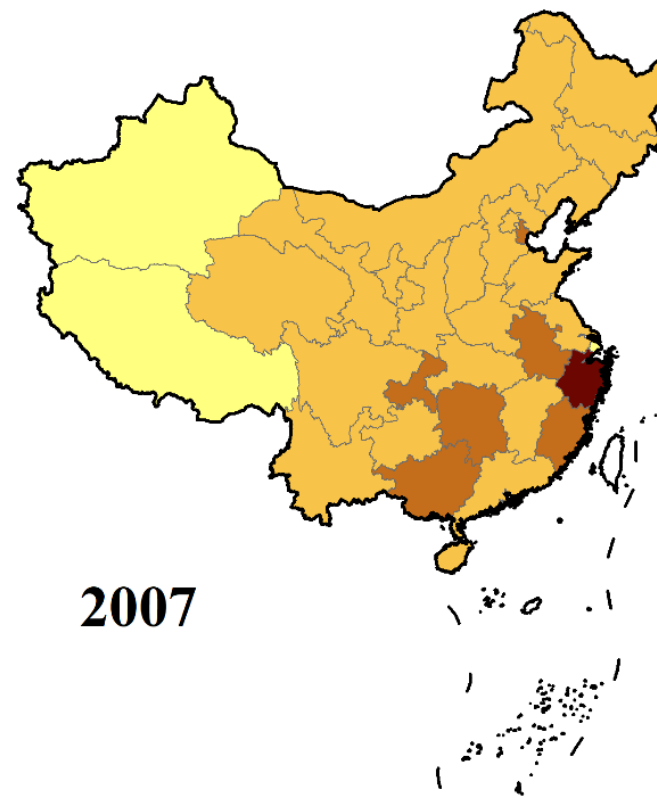

Figure 3. Cont. 




2010
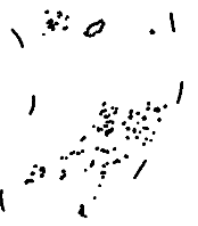

Legend

PPUR (\%)
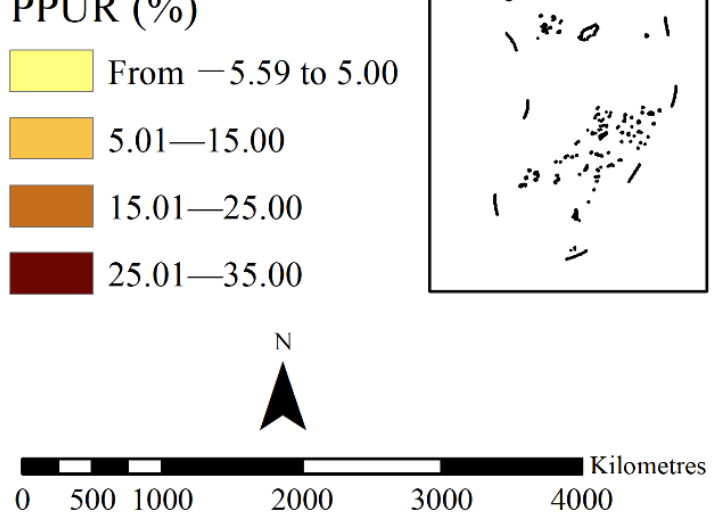

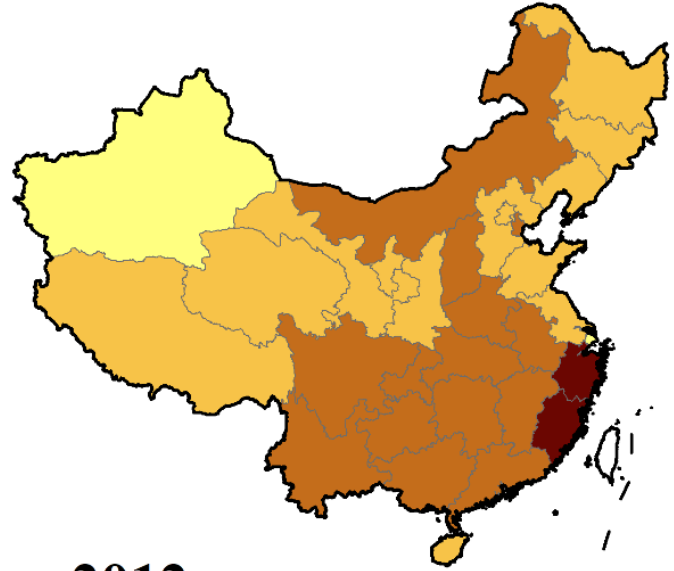

2012

$\because \because 0.1$

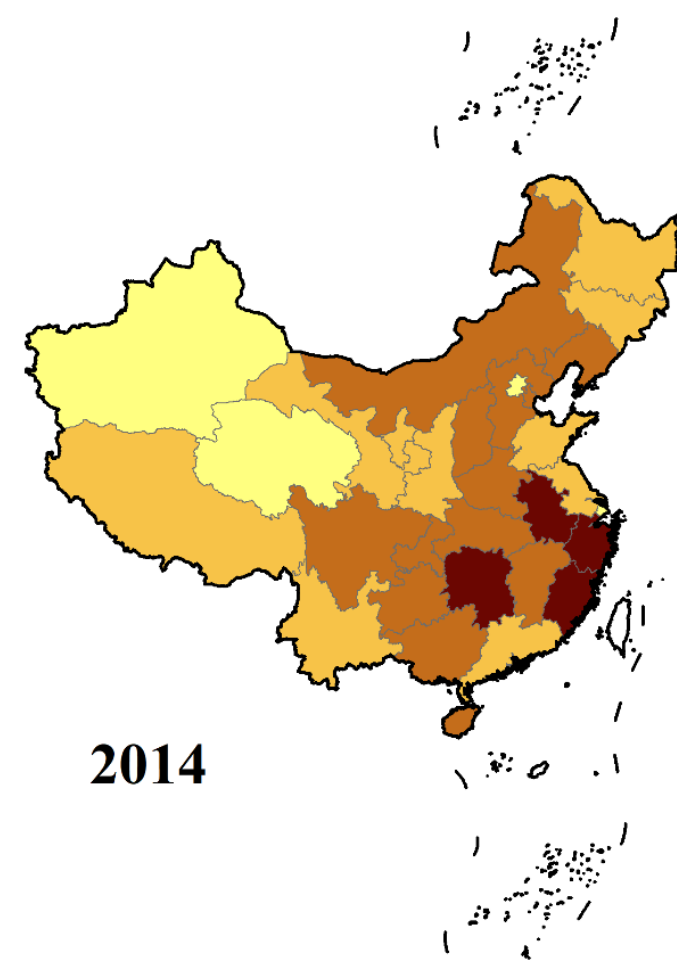

Figure 3. Spatial-temporal transformation of PPUR in 2005-2014. Notes: The highest-degree PPUR [25.01-35.00], the higher-degree [15.01-25.00], the lower-degree [5.01-15.00], the lowest-degree [from -5.59 to 5.00].

\subsubsection{Global Autocorrelation Analysis}

In Table 3, Global Moran's I computed by ArcGIS10.2 in 2005-2014 was all positive, and the majority were significant at 5\% level, which indicates that PPUR in China presents a strong positive spatial autocorrelation, in which the areas with high values of PPUR and the areas with low values of PPUR are respectively clustered in space. Moreover, the value of Global Moran's I increased from 0.119 in 2005 to 0.190 in 2014, roughly showing a clear upward trend of volatility, which suggests that the spatial agglomeration of PPUR was increasing. 
Table 3. Global Moran's I of PPUR.

\begin{tabular}{cccccc}
\hline Year & $\mathbf{2 0 0 5}$ & $\mathbf{2 0 0 6}$ & $\mathbf{2 0 0 7}$ & $\mathbf{2 0 0 8}$ & $\mathbf{2 0 0 9}$ \\
\hline \multirow{2}{*}{ Moran's I } & $0.119^{*}(1.806)$ & $\begin{array}{c}0.158^{* *} \\
(2.244)\end{array}$ & $\begin{array}{c}0.165^{* *} \\
(2.285)\end{array}$ & $\begin{array}{c}0.184^{* *} \\
(2.469)\end{array}$ & $\begin{array}{c}0.170^{* *} \\
(2.282)\end{array}$ \\
\hline Year & $\mathbf{2 0 1 0}$ & $\mathbf{2 0 1 1}$ & $\mathbf{2 0 1 2}$ & $\mathbf{2 0 1 3}$ & $\mathbf{2 0 1 4}$ \\
\hline \multirow{2}{*}{ Moran's I } & $\begin{array}{c}0.205^{* * *} \\
(2.703)\end{array}$ & $\begin{array}{c}0.230^{* * *} \\
(2.957)\end{array}$ & $\begin{array}{c}0.233^{* * *} \\
(2.976)\end{array}$ & $\begin{array}{c}0.233^{* * *} \\
(2.955)\end{array}$ & $\begin{array}{c}0.190^{* *} \\
(2.476)\end{array}$ \\
\hline \multicolumn{2}{l}{ Remarks: Z-values in parentheses. ${ }^{* * *},{ }^{* * *}$ represent significance at the levels of $10 \%, 5 \%, 1 \%$, respectively. }
\end{tabular}

\subsubsection{Local Autocorrelation Analysis}

The LISA cluster diagram of PPUR (Figure 4) is drawn by ArcGIS Pro. In Figure 4, the regions without data are Hong Kong, Macao, and Taiwan, China. Given the 5\% level, Local Moran's I can be divided into five categories: HH (high-high), HL (high-low), LH (low-high), and LL (low-low) clustering areas and nonsignificant areas. The results of Local Moran's I show that China's PPUR in local areas is still dominated by spatial clustering. Local Moran's I which is nonsignificant indicates a random distribution of PPUR in a local range, that includes most eastern provinces. The HL-type indicates that the proportion of ATP in these provinces is significantly higher than the surrounding provinces, but this regional distribution pattern does not appear in Figure 4. The LH-type is the opposite of HL-type, which indicates that ATP is pouring into the neighboring provinces, whereas the number of ATP in central provinces is relatively small, such as Hubei and Shanghai. The LL-type indicates that provinces with lower values of PPUR are surrounded by neighboring provinces with lower values of PPUR, which are located in Western China, and must enhance their economic attractiveness of ATP, such as Xinjiang and Tibet. Finally, the HH-type, in contrast to LL-type, is mainly concentrated in the southeast coastal areas, including Fujian, Hunan, Guangxi, Jiangxi, and Hubei.


Figure 4. Cont. 

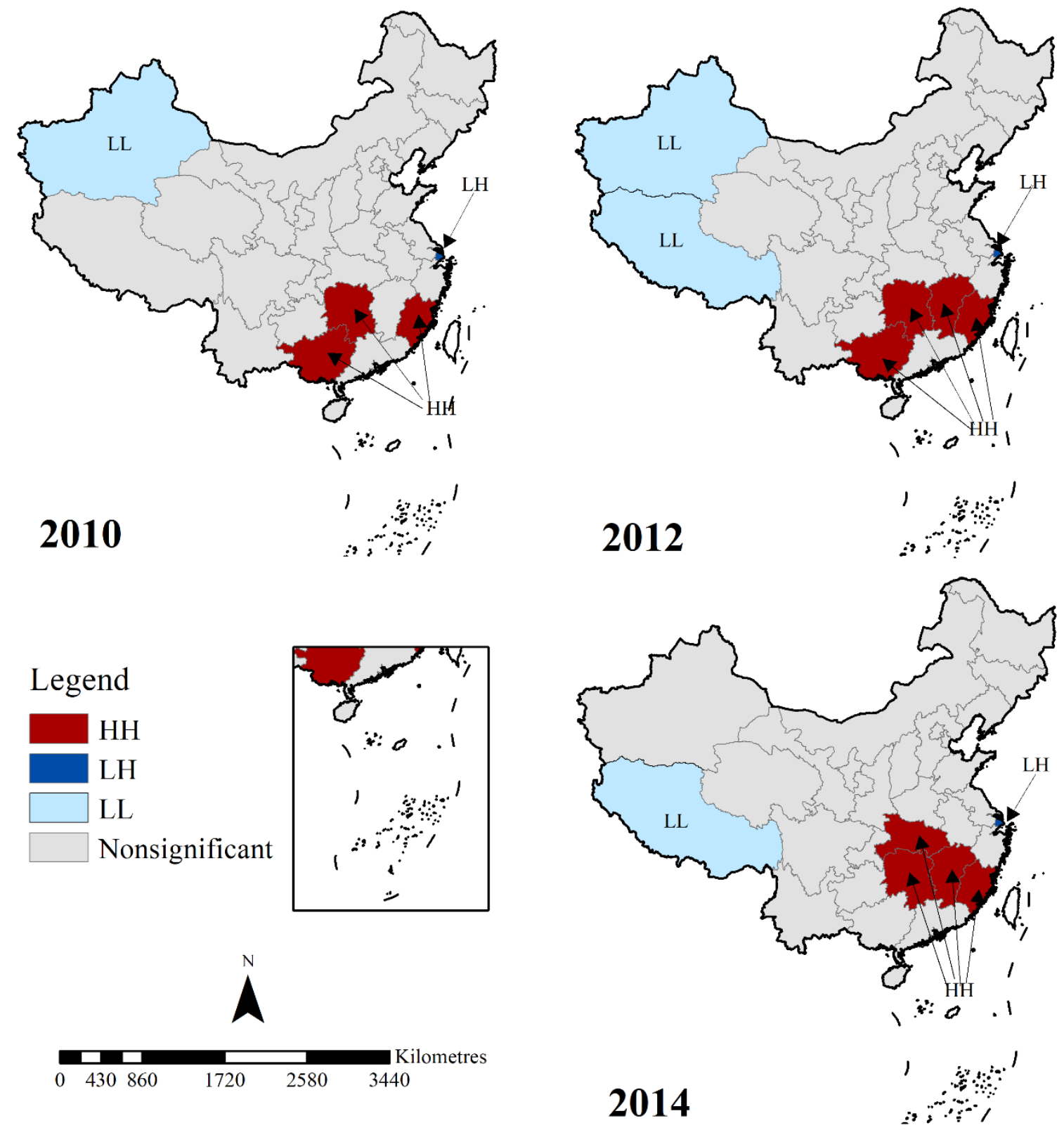

Figure 4. The LISA cluster map of PPUR.

\subsection{Driving Force Analysis Based on URIG}

\subsubsection{Non-spatial Regression Model Analysis}

The results of the non-spatial regression model with four effects in 31 provinces of China in 2005-2014 are shown in Table 4.

In Table 4: (1) The LM spatial lag and the LM spatial error are insignificant when time fixed effects are included, but are significant with non-fixed effects at the $5 \%$ level. In addition, both are significant under the 1\% level in the remaining two fixed effects. Except for significance at the $1 \%$ level with spatial fixed effects and at the $5 \%$ level with dual fixed effects, the robust LM spatial lag is insignificant in others. The robust LM spatial error is insignificant in all of the models. Therefore, non-spatiality can be completely rejected, which is consistent with the conclusion in Figure 3 and Table 3, in which from the perspective of spatial measurement, investigating the impact of URIG on PPUR is reasonable. However, only relying on the (robust) LM tests, we still cannot judge which one of SLM and SEM is used. (2) The LR-test shows that the original hypothesis without spatial fixed effects is rejected (the $p$-value is 0 ), whereas the original hypothesis without 
time fixed effects is accepted (the $p$-value is 0.301), suggesting that adopting a spatial fixed effect model is reasonable.

Table 4. Results of non-spatial panel regression in 2005-2014.

\begin{tabular}{|c|c|c|c|c|}
\hline Variable & $\begin{array}{c}\text { No. of Fixed } \\
\text { Effect }\end{array}$ & $\begin{array}{c}\text { Spatial Fixed } \\
\text { Effects }\end{array}$ & $\begin{array}{l}\text { Time Fixed } \\
\text { Effects }\end{array}$ & $\begin{array}{c}\text { Dual Fixed } \\
\text { Effects }\end{array}$ \\
\hline Intercept & $\begin{array}{l}-11.596 \\
(-1.523)\end{array}$ & - & - & - \\
\hline URIG & $\begin{array}{l}-1.256 \\
(-1.517)\end{array}$ & $\begin{array}{l}2.740 * * * \\
(3.592)\end{array}$ & $\begin{array}{c}-1.055 \\
(-1.379)\end{array}$ & $\begin{array}{l}3.528^{* * *} \\
(4.095)\end{array}$ \\
\hline NS & $\begin{array}{c}32.872 * * * \\
(4.171)\end{array}$ & $\begin{array}{c}30.553^{* * *} \\
(3.291)\end{array}$ & $\begin{array}{c}33.778 * * * \\
(4.649)\end{array}$ & $\begin{array}{c}37.347^{* * * *} \\
(3.765)\end{array}$ \\
\hline $\mathrm{AF}$ & $\begin{array}{l}12.814^{* * *} \\
(5.220)\end{array}$ & $\begin{array}{l}5.894^{* * *} \\
(4.424)\end{array}$ & $\begin{array}{l}6.202 * * \\
(2.513)\end{array}$ & $\begin{array}{l}7.527 * * * \\
(5.317)\end{array}$ \\
\hline FS & $\begin{array}{l}0.208 * * \\
(2.023)\end{array}$ & $\begin{array}{l}0.130 * \\
(1.656)\end{array}$ & $\begin{array}{c}0.016 \\
(0.161)\end{array}$ & $\begin{array}{c}0.117 \\
(1.496)\end{array}$ \\
\hline MR & $\begin{array}{l}-2.652 * * * \\
(-5.036)\end{array}$ & $\begin{array}{l}1.503 * * * \\
(4.512)\end{array}$ & $\begin{array}{l}-5.235^{* * *} \\
(-8.861)\end{array}$ & $\begin{array}{l}1.605^{* * *} \\
(3.955)\end{array}$ \\
\hline $\mathrm{HJ}$ & $\begin{array}{l}-1.768 * * * \\
(-3.018)\end{array}$ & $\begin{array}{c}-0.328 \\
(-1.598)\end{array}$ & $\begin{array}{l}-1.272 * * \\
(-2.309)\end{array}$ & $\begin{array}{l}-0.381 * \\
(-1.842)\end{array}$ \\
\hline LAND & $\begin{array}{l}-21.412 * * \\
(-2.584)\end{array}$ & $\begin{array}{l}39.071^{* * *} \\
(5.013)\end{array}$ & $\begin{array}{l}-27.820 * * * \\
(-3.638)\end{array}$ & $\begin{array}{c}39.813 * * * \\
(5.047)\end{array}$ \\
\hline R-squared & 0.189 & 0.592 & 0.264 & 0.315 \\
\hline Log likelihood & -1008.400 & -633.455 & -981.211 & -627.571 \\
\hline LM spatial lag & $4.346^{* *}$ & $21.032^{* * *}$ & 0.243 & $22.397^{* * *}$ \\
\hline Robust LM spatial lag & 0.006 & $7.684^{* * *}$ & 0.005 & $4.014^{* *}$ \\
\hline LM spatial error & $4.621 * *$ & $13.665^{* * *}$ & 0.309 & $18.398 * * *$ \\
\hline $\begin{array}{c}\text { Robust LM spatial } \\
\text { error }\end{array}$ & 0.282 & 0.317 & 0.072 & 0.015 \\
\hline \multirow{3}{*}{$\begin{array}{l}\text { LR-test joint } \\
\text { significance }\end{array}$} & Fixed effect & Statistic & $\begin{array}{l}\text { Degrees of } \\
\text { freedom }\end{array}$ & Probability \\
\hline & $\begin{array}{c}\text { Spatial fixed } \\
\text { effects }\end{array}$ & 707.280 & 31 & 0.000 \\
\hline & $\begin{array}{l}\text { Time fixed } \\
\text { effects }\end{array}$ & 11.767 & 10 & 0.301 \\
\hline
\end{tabular}

Remarks: T-values in parentheses. ${ }^{*},{ }^{* *},{ }^{* * *}$ represent significance at the levels of $10 \%, 5 \%, 1 \%$, respectively.

Considering that SLM and SEM have not been estimated in advance, these hypotheses can only be made in the form of a Wald test. Following the (robust) LM tests, this study first considers the establishment of SDM, and then determines whether it can be simplified into SLM or SEM according to the Wald test. Table 5 provides the estimated results of the Wald test and the Hausman test.

Table 5. Wald test and Hausman test.

\begin{tabular}{ccc}
\hline Test & Statistic & Probability \\
\hline Wald spatial lag & 29.230 & $1.314 \times 10^{-4}$ \\
(Hypothesis 1) & 30.517 & $7.631 \times 10^{-5}$ \\
Wald spatial error & 15.883 & 0.390 \\
(Hypothesis 2) & Hausman test & \\
\hline
\end{tabular}

In Table 5, the Wald spatial lag and the Wald spatial error tests refuse to be simplified into SLM and SEM at the 1\% level. The conclusion drawn from the estimated results of the Wald test is that the SDM model is adopted. Through the (robust) LM tests, either SLM or SEM should be adopted. However, in view of the fact that SDM is the generalization of SLM and SEM, SDM is selected as the basic model for analysis. The Hausman test reveals that random effects should replace fixed effects. However, if the observation unit is a large 
geographical area (provincial-level administrative unit) and the total data are used [31], then fixed effects are almost always more convincing than random effects. Therefore, the former is adopted. Ultimately, the study selects SDM with the spatial fixed effect.

\subsubsection{Robustness Test}

To guarantee that the spatial autocorrelation of PPUR is not accidental, in addition to the economic distance weight used in Section 3.2.1, the geographical adjacency matrix and geographical distance matrix are adopted to estimate the SDM with the spatial fixed effect. The results are shown in Table 6.

Table 6. Estimation results of three spatial weight matrices.

\begin{tabular}{|c|c|c|c|}
\hline Variable & $\begin{array}{c}\text { Geographic } \\
\text { Adjacency Matrix }\end{array}$ & $\begin{array}{c}\text { Geographic Distance } \\
\text { Matrix }\end{array}$ & $\begin{array}{c}\text { Economic Distance } \\
\text { Matrix }\end{array}$ \\
\hline URIG & $\begin{array}{c}3.058^{* * *} \\
(3.105)\end{array}$ & $\begin{array}{c}3.442^{* * *} \\
(4.265)\end{array}$ & $\begin{array}{c}2.958^{* * *} \\
(3.640)\end{array}$ \\
\hline NS & $\begin{array}{c}32.602^{* * *} \\
(3.287)\end{array}$ & $\begin{array}{c}37.373^{* * * *} \\
(3.892)\end{array}$ & $\begin{array}{c}33.820^{* * *} \\
(3.594)\end{array}$ \\
\hline $\mathrm{AF}$ & $\begin{array}{c}7.019 * * * \\
(4.845)\end{array}$ & $\begin{array}{l}6.325^{* * *} \\
(4.673)\end{array}$ & $\begin{array}{c}5.801 * * * \\
(4.252)\end{array}$ \\
\hline FS & $\begin{array}{c}0.128 \\
(1.570)\end{array}$ & $\begin{array}{l}0.205^{* *} \\
(2.529)\end{array}$ & $\begin{array}{l}0.136^{*} \\
(1.719)\end{array}$ \\
\hline MR & $\begin{array}{l}1.504^{* * *} \\
(2.728)\end{array}$ & $\begin{array}{c}1.426^{* * *} \\
(3.729)\end{array}$ & $\begin{array}{c}1.695^{* * *} \\
(4.185)\end{array}$ \\
\hline $\mathrm{HJ}$ & $\begin{array}{l}-0.311 \\
(-1.474)\end{array}$ & $\begin{array}{l}-0.336^{*} \\
(-1.663)\end{array}$ & $\begin{array}{c}-0.214 \\
(-1.075)\end{array}$ \\
\hline LAND & $\begin{array}{c}39.590^{* * * *} \\
(4.804)\end{array}$ & $\begin{array}{l}40.268^{* * * *} \\
(5.166)\end{array}$ & $\begin{array}{c}48.697^{* * *} \\
(5.783)\end{array}$ \\
\hline $\mathrm{W}^{*} \mathrm{URIG}$ & $\begin{array}{l}-2.899 * \\
(-1.844)\end{array}$ & $\begin{array}{l}-4.293^{* * *} \\
(-3.077)\end{array}$ & $\begin{array}{c}-0.964 \\
(-0.738)\end{array}$ \\
\hline $\mathrm{W}^{*} \mathrm{NS}$ & $\begin{array}{l}23.974 \\
(1.260)\end{array}$ & $\begin{array}{l}-15.274 \\
(-0.918)\end{array}$ & $\begin{array}{c}-33.042^{* *} \\
(-2.187)\end{array}$ \\
\hline $\mathrm{W}^{*} \mathrm{AF}$ & $\begin{array}{l}-6.751^{* *} \\
(-2.520)\end{array}$ & $\begin{array}{c}3.731 \\
(1.495)\end{array}$ & $\begin{array}{c}2.507 \\
(1.122)\end{array}$ \\
\hline Log likelihood & -628.564 & -614.832 & -611.667 \\
\hline$W^{*} \mathrm{FS}$ & $\begin{array}{c}0.162 \\
(1.028)\end{array}$ & $\begin{array}{l}-0.192 \\
(-1.380)\end{array}$ & $\begin{array}{l}-0.320 * * \\
(-2.103)\end{array}$ \\
\hline $\mathrm{W}^{*} \mathrm{MR}$ & $\begin{array}{c}-0.585 \\
(-0.658)\end{array}$ & $\begin{array}{c}-0.721 \\
(-1.023)\end{array}$ & $\begin{array}{c}0.919 \\
(1.447)\end{array}$ \\
\hline $\mathrm{W}^{*} \mathrm{HJ}$ & $\begin{array}{l}-0.075 \\
(-0.167)\end{array}$ & $\begin{array}{c}0.511 \\
(1.511)\end{array}$ & $\begin{array}{l}0.688^{* *} \\
(2.242)\end{array}$ \\
\hline$W^{*}$ LAND & $\begin{array}{l}-4.892 \\
(-0.351)\end{array}$ & $\begin{array}{l}11.808 \\
(0.912)\end{array}$ & $\begin{array}{c}22.064^{* *} \\
(2.028)\end{array}$ \\
\hline$\rho$ & $\begin{array}{c}2.7 \times 10^{-5} \\
\left(3.46 \times 10^{-4}\right)\end{array}$ & $\begin{array}{l}-0.184^{* *} \\
(-2.542)\end{array}$ & $\begin{array}{l}-0.233^{* * *} \\
(-3.787)\end{array}$ \\
\hline R-squared & 0.930 & 0.937 & 0.939 \\
\hline $\mathrm{N}$ & 310 & 310 & 310 \\
\hline
\end{tabular}

Notes: T-values in parentheses. ${ }^{*},{ }^{* *},{ }^{* * *}$ represent significance at the levels of $10 \%, 5 \%, 1 \%$, respectively.

The spatial autoregressive coefficients ( $\rho$ ) of SDM using the geographic distance matrix and economic distance matrix are significantly negative, which indicates that adopting the spatial econometric analysis is necessary, and that the increase of PPUR in this province has an inhibitory effect on the PPUR of neighboring provinces. In estimating results using different spatial weights, except that $\mathrm{HJ}$ has a tendency to inhibit PPUR (significant at the $10 \%$ level only when using the geographic distance matrix), URIG and other control variables almost significantly promote PPUR, indicating that the model has good robustness. In the non-spatial model, the parameter estimates represent the marginal effects of independent variables, whereas the estimation coefficient of SDM does not have the same meaning due to the existence of spatial lag terms. Referring to the 
method proposed by Lesage and Pace [30], the present study decomposes the influence of independent variables into direct and indirect effects. The former represents the marginal effect of the change of independent variables on the PPUR of the province, whereas the latter represents the marginal effect of the change of independent variables on the PPUR of the surrounding provinces. The sum of the two is the total effect [28].

\subsubsection{Comparative Analysis of Direct and Indirect Effects}

The effect decomposition of independent variables in SDM under three spatial weights is presented in Table 7. Although spatial weights are different, the direct effects of the same independent variable are almost the same. Considering that the economic distance weight considers the regional economic level and $\rho$ is significant, this study takes the results of SDM under the economic distance weight as examples to analyze the influence of each variable on PPUR.

In Table 7, URIG significantly promotes the increase of the PPUR of the province, but inhibits the increase of PPUR in neighboring areas, and the latter is not significant. With the other factors unchanged, if URIG increases by one unit, then the PPUR of the province significantly increases by 3.119 units on average, whereas the PPUR of the surrounding provinces decreases by 1.503 units. For every unit of growth in NS, AF, and FS, the PPUR of the province significantly increases by $37.975,5.779$, and 0.170 units, respectively. The increase of the PPUR of the surrounding provinces is significantly inhibited, but AF promotes the increase of the PPUR of the surrounding provinces, inconspicuously. The specific performance of MR is that the increase of one bed per 1000 people increases the PPUR of the province and neighboring provinces by 1.665 and 0.450 units, respectively, but the latter is insignificant. The larger the HJ, the lower the PPUR of the province is, and the higher the PPUR of neighboring provinces is, then the former is insignificant. LAND promotes the growth of PPUR of the province and neighboring provinces, but the latter is not significant.

Table 7. Decomposition of the effects of independent variables on PPUR.

\begin{tabular}{|c|c|c|c|c|}
\hline Variable & Effect & $\begin{array}{c}\text { Geographic } \\
\text { Adjacency Matrix }\end{array}$ & $\begin{array}{c}\text { Geographic } \\
\text { Distance Matrix }\end{array}$ & $\begin{array}{c}\text { Economic } \\
\text { Distance Matrix }\end{array}$ \\
\hline \multirow[b]{2}{*}{ URIG } & Direct effect & $\begin{array}{c}3.109 * * * \\
(3.094)\end{array}$ & $\begin{array}{c}3.696^{* * *} \\
(4.510)\end{array}$ & $\begin{array}{c}3.119 * * * \\
(3.631)\end{array}$ \\
\hline & Indirect effect & $\begin{array}{l}-2.967 * \\
(-1.837)\end{array}$ & $\begin{array}{l}-4.418^{* * *} \\
(-3.439)\end{array}$ & $\begin{array}{l}-1.503 \\
(-1.214)\end{array}$ \\
\hline \multirow{4}{*}{ NS } & Total & $\begin{array}{c}0.142 \\
(0.087)\end{array}$ & $\begin{array}{c}-0.722 \\
(-0.574)\end{array}$ & $\begin{array}{c}1.616 \\
(1.479)\end{array}$ \\
\hline & Direct effect & $\begin{array}{c}33.038^{* * *} \\
(3.300)\end{array}$ & $\begin{array}{c}38.051^{* * * *} \\
(3.862)\end{array}$ & $\begin{array}{c}37.975^{* * * *} \\
(3.815)\end{array}$ \\
\hline & Indirect effect & $\begin{array}{l}24.695 \\
(1.357)\end{array}$ & $\begin{array}{l}-18.861 \\
(-1.281)\end{array}$ & $\begin{array}{l}-38.049 * * \\
(-2.694)\end{array}$ \\
\hline & Total & $\begin{array}{c}57.733^{* * *} \\
(2.807)\end{array}$ & $\begin{array}{l}19.190 \\
(1.342)\end{array}$ & $\begin{array}{l}-0.074 \\
(-0.005)\end{array}$ \\
\hline \multirow{2}{*}{$\mathrm{AF}$} & Direct effect & $\begin{array}{c}7.091 * * * \\
(5.022)\end{array}$ & $\begin{array}{c}6.176^{* * *} \\
(4.495)\end{array}$ & $\begin{array}{c}5.779 * * * \\
(4.179)\end{array}$ \\
\hline & Indirect effect & $\begin{array}{l}-6.840^{* *} \\
(-2.455)\end{array}$ & $\begin{array}{c}2.391 \\
(1.073)\end{array}$ & $\begin{array}{c}1.015 \\
(0.493)\end{array}$ \\
\hline \multirow{4}{*}{ FS } & Total & $\begin{array}{c}0.251 \\
(0.089)\end{array}$ & $\begin{array}{c}8.567 * * * \\
(3.606)\end{array}$ & $\begin{array}{c}6.794^{* * *} \\
(3.349)\end{array}$ \\
\hline & Direct effect & $\begin{array}{c}0.122 \\
(1.471)\end{array}$ & $\begin{array}{l}0.219^{* *} \\
(2.635)\end{array}$ & $\begin{array}{l}0.170 \text { ** } \\
(2.050)\end{array}$ \\
\hline & Indirect effect & $\begin{array}{c}0.172 \\
(1.085)\end{array}$ & $\begin{array}{l}-0.213 \text { * } \\
(-1.713)\end{array}$ & $\begin{array}{l}-0.319 * * \\
(-2.263)\end{array}$ \\
\hline & Total & $\begin{array}{l}0.294^{*} \\
(1.755)\end{array}$ & $\begin{array}{c}0.006 \\
(0.040)\end{array}$ & $\begin{array}{c}-0.148 \\
(-1.053)\end{array}$ \\
\hline
\end{tabular}


Table 7. Cont.

\begin{tabular}{|c|c|c|c|c|}
\hline Variable & Effect & $\begin{array}{c}\text { Geographic } \\
\text { Adjacency Matrix }\end{array}$ & $\begin{array}{c}\text { Geographic } \\
\text { Distance Matrix }\end{array}$ & $\begin{array}{c}\text { Economic } \\
\text { Distance Matrix }\end{array}$ \\
\hline \multirow{3}{*}{ MR } & Direct effect & $\begin{array}{l}1.490 * * \\
(2.721)\end{array}$ & $\begin{array}{c}1.464^{* * *} \\
(3.709)\end{array}$ & $\begin{array}{c}1.665^{* * *} \\
(4.065)\end{array}$ \\
\hline & Indirect effect & $\begin{array}{c}-0.596 \\
(-0.646)\end{array}$ & $\begin{array}{l}-0.887 \\
(-1.423)\end{array}$ & $\begin{array}{c}0.450 \\
(0.761)\end{array}$ \\
\hline & Total & $\begin{array}{c}0.893 \\
(1.105)\end{array}$ & $\begin{array}{c}0.577 \\
(0.895)\end{array}$ & $\begin{array}{c}2.116^{* * *} \\
(3.568)\end{array}$ \\
\hline \multirow{2}{*}{$\mathrm{HJ}$} & Direct effect & $\begin{array}{c}-0.323 \\
(-1.558)\end{array}$ & $\begin{array}{l}-0.354 \text { * } \\
(-1.735)\end{array}$ & $\begin{array}{c}-0.292 \\
(-1.461)\end{array}$ \\
\hline & Indirect effect & $\begin{array}{c}-0.088 \\
(-0.120)\end{array}$ & $\begin{array}{c}0.504 \\
(1.657)\end{array}$ & $\begin{array}{l}0.679 * * \\
(2.396)\end{array}$ \\
\hline \multirow{4}{*}{ LAND } & Total & $\begin{array}{c}-0.411 \\
(-0.831)\end{array}$ & $\begin{array}{c}0.150 \\
(0.499)\end{array}$ & $\begin{array}{c}0.388 \\
(1.260)\end{array}$ \\
\hline & Direct effect & $\begin{array}{c}39.150^{* * *} \\
(4.712)\end{array}$ & $\begin{array}{c}40.481^{* * *} \\
(5.012)\end{array}$ & $\begin{array}{c}48.009^{* * *} \\
(5.426)\end{array}$ \\
\hline & Indirect effect & $\begin{array}{c}-5.037 \\
(-0.357)\end{array}$ & $\begin{array}{c}4.026 \\
(0.369)\end{array}$ & $\begin{array}{c}9.713 \\
(0.963)\end{array}$ \\
\hline & Total & $\begin{array}{c}34.113 * * \\
(2.042)\end{array}$ & $\begin{array}{l}44.507^{* * *} \\
(3.377)\end{array}$ & $\begin{array}{c}57.723^{* * *} \\
(6.140)\end{array}$ \\
\hline
\end{tabular}

Remarks: T-values in parentheses. ${ }^{*},{ }^{* *},{ }^{* * *}$ represent significance at the levels of $10 \%, 5 \%, 1 \%$, respectively.

\subsubsection{Regional Spatial Regression Analysis}

In consideration of the heterogeneity of the influence of URIG on PPUR amongst regions in Figure 3, this research further investigates the influence in Eastern, Central, and Western China, according to the division scope in Figure 2. In view of space constraints, the relevant tests and model screenings in Eastern, Central, and Western China are not specifically displayed, and only the various effects of the final model are compared and analyzed. The results are shown in Table 8.

Table 8. Estimation results of spatial differences amongst Eastern, Central, and Western China.

\begin{tabular}{|c|c|c|c|c|}
\hline Variable & Effect & Eastern China & Central China & Western China \\
\hline \multirow{3}{*}{ URIG } & Direct effect & $\begin{array}{l}-3.130 * * \\
(-2.338)\end{array}$ & $\begin{array}{c}0.220 \\
(0.099)\end{array}$ & $\begin{array}{c}5.195^{* * *} \\
(4.645)\end{array}$ \\
\hline & & $-7.044^{* * *}$ & $-12.479 * * *$ & $4.235^{*}$ \\
\hline & Indirect effect & $(-3.609)$ & $(-3.541)$ & $(2.069)$ \\
\hline \multirow{5}{*}{ NS } & Total & $\begin{array}{c}-10.174^{* * *} \\
(-4.919)\end{array}$ & $\begin{array}{c}-12.259 * * \\
(-2.821)\end{array}$ & $\begin{array}{c}9.430 * * * \\
(4.323)\end{array}$ \\
\hline & Direct effect & $\begin{array}{c}75.542 * * * \\
(4.465)\end{array}$ & $\begin{array}{l}24.342 \\
(1.380)\end{array}$ & $\begin{array}{l}14.228 \\
(0.867)\end{array}$ \\
\hline & Indirect effect & 32.454 & 19.016 & -27.591 \\
\hline & mairect еirect & $(1.289)$ & $(0.602)$ & $(-0.953)$ \\
\hline & Total & $\begin{array}{c}107.996^{* * *} \\
(3.807)\end{array}$ & $\begin{array}{l}43.358 \\
(1.010)\end{array}$ & $\begin{array}{l}-13.363 \\
(-0.457)\end{array}$ \\
\hline \multirow{2}{*}{$\mathrm{AF}$} & Direct effect & $\begin{array}{c}2.037 \\
(1.415)\end{array}$ & $\begin{array}{c}11.784^{* *} \\
(3.126)\end{array}$ & $\begin{array}{l}6.267 * \\
(2.138)\end{array}$ \\
\hline & Indirect effect & $\begin{array}{c}0.416 \\
(0.226)\end{array}$ & $\begin{array}{l}-13.225^{*} \\
(-1.972)\end{array}$ & $\begin{array}{c}17.561 * * * \\
(3.250)\end{array}$ \\
\hline \multirow{4}{*}{ FS } & Total & $\begin{array}{c}2.453 \\
(1.089)\end{array}$ & $\begin{array}{c}-1.441 \\
(-0.170)\end{array}$ & $\begin{array}{c}23.827^{* * *} \\
(4.415)\end{array}$ \\
\hline & Direct effect & $\begin{array}{l}0.149 * \\
(1.909)\end{array}$ & $\begin{array}{l}0.467 * \\
(2.062)\end{array}$ & $\begin{array}{l}0.244 \text { * } \\
(1.960)\end{array}$ \\
\hline & Indirect effect & $\begin{array}{c}-0.302 \\
(-1.780)\end{array}$ & $\begin{array}{c}0.543 \\
(1.011)\end{array}$ & $\begin{array}{c}0.046 \\
(0.184)\end{array}$ \\
\hline & Total & $\begin{array}{c}-0.152 \\
(-0.988)\end{array}$ & $\begin{array}{c}1.009 \\
(1.584)\end{array}$ & $\begin{array}{c}0.290 \\
(1.062)\end{array}$ \\
\hline
\end{tabular}


Table 8. Cont.

\begin{tabular}{|c|c|c|c|c|}
\hline Variable & Effect & Eastern China & Central China & Western China \\
\hline \multirow{4}{*}{ MR } & \multirow{2}{*}{ Direct effect } & -0.489 & $4.294^{* * *}$ & 0.612 \\
\hline & & $(-0.687)$ & $(4.137)$ & $(0.888)$ \\
\hline & \multirow{2}{*}{ Indirect effect } & $2.820 * *$ & -1.331 & -0.510 \\
\hline & & $(2.842)$ & $(-0.706)$ & $(-0.422)$ \\
\hline \multirow{8}{*}{$\mathrm{HJ}$} & \multirow{2}{*}{ Total } & $2.331^{* * * *}$ & 2.963 & 0.102 \\
\hline & & $(4.164)$ & (1.518) & $(0.072)$ \\
\hline & \multirow{2}{*}{ Direct effect } & 0.276 & -0.726 & -0.003 \\
\hline & & $(1.425)$ & $(-1.762)$ & $(-0.185)$ \\
\hline & \multirow{2}{*}{ Indirect effect } & -0.376 & 0.044 & -0.096 \\
\hline & & $(-1.402)$ & $(0.063)$ & $(-1.363)$ \\
\hline & & -0.100 & -0.682 & -0.099 \\
\hline & Total & $(-0.344)$ & $(-0.826)$ & $(-1.297)$ \\
\hline \multirow{6}{*}{ LAND } & & -7.369 & $156.412 * * *$ & $65.046^{* * *}$ \\
\hline & & $(-0.864)$ & (3.474) & (6.367) \\
\hline & \multirow{2}{*}{ Indirect effect } & -2.526 & -209.939 * & 21.830 \\
\hline & & $(-0.181)$ & $(-1.889)$ & $(1.520)$ \\
\hline & \multirow{2}{*}{ Total } & -9.895 & -53.527 & $86.875^{* * *}$ \\
\hline & & $(-0.687)$ & $(-0.409)$ & $(4.500)$ \\
\hline \multirow{2}{*}{\multicolumn{2}{|c|}{$\rho$}} & $-0.345^{* * *}$ & $-0.258 *$ & 0.111 \\
\hline & & $(-3.566)$ & $(-1.908)$ & (1.155) \\
\hline \multicolumn{2}{|c|}{ R-squared } & 0.981 & 0.970 & 0.940 \\
\hline \multicolumn{2}{|c|}{$\mathrm{N}$} & 110 & 80 & 120 \\
\hline \multicolumn{2}{|c|}{ Log likelihood } & -166.136 & -122.154 & -224.119 \\
\hline
\end{tabular}

Through the $\rho$, a spatial autocorrelation is found at the 1\% level in Eastern China and at the $10 \%$ level in Central China. However, the increase of PPUR in this province leads to the increase of PPUR in neighboring areas in Western China, which is different from the national results. In Central and Western China, the widening URIG contributes to the increase of PPUR, but not significantly in Central China. For Eastern China, URIG significantly inhibits the increase of PPUR, which is different from the national results. The impacts of NS, AF, and FS on PPUR in regions are consistent with those on the whole country. However, only in Eastern China NS is significant, AF is insignificant. Only the MR of Eastern China has the opposite effect on PPUR compared with the national results. Although the impact of MR on PPUR in Central and Western China is consistent with the national results, the latter is not significant. Only the effect of HJ and LAND on PPUR in Eastern China contradicts the national results.

\section{Discussion}

\subsection{The Nationwide Influence of URIG and Other Factors}

Across the country, studies have found that the widening URIG intensifies PPUR, which is consistent with the conclusion of the Todaro migration model [23]. The reason is due to income disparities amongst regions and between urban and rural areas, coupled with the strict household registration system. Specifically, URIG promotes the continuous flow of plentiful surplus labors to large and medium-sized cities in search of employment opportunities. However, due to the restrictions of settlement policies, the speed of ATP from rural areas to urban areas is much faster than the ATP from agricultural to non-agricultural hukou, in which the growth of URPP is faster than URHRP, that eventually leads to the gradual ascension of PPUR. The prosperity of urban economy not only promotes the scale and industrialization of agriculture, but also spawns a huge amount of agricultural surplus labor. Driven by comparative economic interests, ATP continues to flow to nonagricultural sectors, and the type of migration gradually develops from individual to family migration [32]. Changes in housing demand caused by population mobility lead to high housing prices, whereas the growth of wages of ATP engaging in labor-intensive industries 
lags far behind the rising of housing prices [33]. Faced with a large amount of urban population inflow, local governments have formulated a score-based entry evaluation system, including house purchase indicators, to accommodate the high-quality population. Therefore, ATP attracted by URIG has eventually become a peri-urbanization population due to the difficulty in obtaining urban hukou. Note that URIG has a negative spillover effect on the PPUR of neighboring provinces. The reason is that the expansion of URIG in the province has attracted more ATP from other provinces, thereby reducing the inflow or increasing the loss of ATP in other provinces.

The positive effects of NS and AF on PPUR can be explained by the increasing employment opportunities. Compared with purely agricultural production, secondary industries have indeed raised the income to a large extent. Therefore, massive ATP has flooded into cities to seek non-agricultural employment opportunities. The prosperity of tertiary industries, which are labor-intensive with low technical requirements, can also provide additional non-agricultural job opportunities for ATP. The continuous strengthening of secondary and tertiary industries has attracted an increasing number of ATPs to gather in cities, thereby greatly improving URPP. The higher the AF in a region, the more dynamic the region's economy is, and the more jobs can be created to absorb ATP. Nevertheless, due to the strict settlement policies formulated by local governments, the pace of ATP turning into urban household residents has not kept pace, ultimately improving PPUR.

FS accelerates PPUR by improving the city's comprehensive carrying capacity. The improvement of urban physical and service facilities can raise the quality of life of citizens. The higher the level of municipal public services, the stronger the comprehensive carrying capacity of the city, and the more ATP can be attracted, thus promoting the process of the peri-urbanization of rural population.

The larger the MR, the more it can attract ATP to large and medium-sized cities, thus promoting PPUR. Nationally, the more hospital beds per capita, the higher the level of health care, and the more ATP who pursues high quality of life can flow to these regions to obtain better medical resources and guarantee a higher standard of living.

Only $\mathrm{HJ}$ is found to negatively correlate with PPUR, which is consistent with the article of Ji and Zhong [20]. This result may be explained by the growth rate of URHRP, which is relatively faster than URPP. On the one hand, considering that the existence of the dual urban-rural household registration system has seriously hindered the pace of China's people-oriented urbanization, local governments are gradually liberalizing the restrictions of the urban household registration system and implementing the reform of CHRS, such as loosening urban household registration to ATP [34]. Large cities dominated by provincial capitals have easy access to good jobs, children's education, medical resources, and the right to settle in cities permanently. Therefore, ATP tends to stay in large cities, rather than choosing to settle in small cities or return to the countryside $[35,36]$. With the intensification of the reform of CHRS, an increasing number of permanent migrants have settled in cities and become citizens, and URHRP has risen sharply. On the other hand, however, the urban carrying capacity is limited, coupled with the ageing of migrant workers and the reduction of new agricultural transferable population. Moreover, the number of urban resident populations has not changed significantly, namely, URPP remains unchanged or increases slightly. The above two reasons make URHRP increase faster than the growth rate of URPP and ultimately results in a downward trend for PPUR.

Moreover, LAND promotes PPUR by improving the city's carrying capacity. Land is the carrier and people are the load. The increase in urbanization will inevitably boost the prosperity of industrialization, which leads to the continuous transformation of various types of land around cities, such as agricultural land and forest land into urban construction land, which is the improvement of land-centered urbanization. Industrial agglomeration not only accelerates the continuous growth of urban construction land area, but also attracts a large number of ATP to cities to engage in non-agricultural work. However, these ATPs can rarely change from agricultural hukou to non-agricultural hukou, which promotes PPUR. 


\subsection{Spatial Differences amongst Regions}

At the regional level, except for NS, AF, and FS, URIG and other control variables are found to have different effects on PPUR compared with the national results (Table 8). First, the expansion of URIG has promoted the increase of PPUR in Central and Western China, but inhibited the increase of PPUR in Eastern China, which can be understood as the impact of URIG on PPUR varies with different economic levels. Compared with Central and Western China, although Eastern China has stronger economic strength and higher wage levels, the cost of living in cities should also be considered for ATP. However, the shortage of land supply in Eastern China largely contributes to soaring house prices, which increase the housing cost of ATP and ultimately reduce the inflow of ATP or force ATP to leave the eastern cities. Second, MR in Eastern China has a negative impact on PPUR. The medical level in Eastern China is significantly higher than the Central and Western China, but the limited medical resources per capital makes it difficult for ATP with meagre income to access and afford long-term medical care, thus fleeing the large cities and reducing PPUR. Third, compared with Central and Western China, HJ in Eastern China has a positive impact on PPUR. In general, lowering the threshold of urban settlement only increases URHRP and reduces PPUR. However, the eastern region has unique advantages in terms of career development prospects, educational resources, and medical standards. Lowering the threshold of settlement only attracts more ATP to the eastern developed regions, thereby boosting PPUR. Fourth, LAND in Eastern China has an inhibitory effect on PPUR. The total land area of administrative region of each city is fixed. With the acceleration of development in recent years, there is less incremental urban land available for development. The scarcity of land resources leads to the rise of land prices. Therefore, those low-tech labor-intensive industries have to be transferred from eastern cities to central and western cities or Southeast Asian countries. Although the area of urban built-up areas is increasing and land-centered urbanization is improving every year, the job opportunities suitable for ATP have not increased at the same time. The reduction of job opportunities reduces the attractiveness of ATP from the inflow side or increases the departure of ATP from the output side, and ultimately reduces PPUR.

\subsection{Policy Implications}

From a national perspective, the reduction of PPUR calls for policy intervention, such as achieving urban-rural integration, narrowing URIG, and reducing the inflow of ATP. First, in areas that attract ATP, the government must actively resolve the urban hukou and housing problems of agricultural migrants who meet the requirements for settlement in different categories, thereby reducing the number of peri-urbanized populations. Second, reducing the number of ATP in large and medium-sized cities from the inflow end can be achieved by narrowing the income gap between urban and rural areas. In terms of employment, the authorities should reinforce financial and technical support for rural enterprises; reverse the urban bias in price, investment, and fiscal expenditure; and promote the balanced development of regional economy to provide employment opportunities for rural surplus labor and improve remuneration. In addition to developing the rural economy, the focus should also be placed on the balanced development of large, medium, and small cities, including the balanced development of central and western regions. Regarding life, the government is supposed to increase the investment of high-quality education and medical resources and strive to improve the quality of life in rural areas.

The reform of household registration system is implemented at different levels throughout the country, and the emphasis must be placed on the 'citizenisation' of the 200-300 million ATPs, thereby increasing URHRP and reducing PPUR. For megacities, to prevent population overcrowding and the declining quality of life, local governments may formulate the implementation rules of conditional settlement on the basis of its own functional positioning and urban comprehensive carrying capacity, thereby relieving the rise of PPUR. For large cities, local governments must focus on the urbanization of the suburbs and orderly guide population flow to new suburbs, thus alleviating the popula- 
tion pressure of urban centers. For small and medium-sized cities, the urban settlement conditions should be relaxed. For small towns, the household registration system can be completely liberalized to encourage ATP to urbanize locally.

At the regional level, two main suggestions are worthy of reference. On the one hand, in Eastern China, local governments must appropriately increase the supply of land resources and cool the overheated housing market to reduce the living costs of ATP, especially housing and medical costs. For Eastern China, guiding labor-intensive and capital-intensive industries is critical to gradually transform into knowledge-intensive industries, thereby reducing the demand for agricultural migrants. On the other hand, Central and Western China are supposed to optimize the layout of industrial structure, increase employment opportunities, and introduce high-quality education and medical resources to improve the attractiveness of talents. Systematically accommodating labor-intensive and partly capital-intensive industries transferred from Eastern China and cultivating new economic growth poles centered on provincial capitals are urgent, allowing ATP that originally flowed to Eastern China to gradually divert to Central and Western China, thereby alleviating the population pressure of eastern cities.

Moreover, the impact of China's URIG on PPUR has reference significance for other developing countries. On the one hand, China's population peri-urbanization is also land peri-urbanization from the perspective of migrants working in manufacturing located in the suburbs of built-up cities. The most notable characteristics of peri-urbanized areas located on the outskirts of established cities are massive loss of farmland, inefficient use of land resources, disorderly competition, and uncoordinated development. For developing countries with high population density and scarce land resources, the urgent task is to formulate reasonable land planning, optimize industrial structure, and attract external investment, in order to create more employment opportunities and narrow the gap between the rich and the poor. In order to alleviate population congestion, it is the basic transportation construction that is also necessary to improve the connectivity and convenience of rural and urban areas. On the other hand, China's population periurbanization essentially indicates that the floating population enjoys differentiated social welfare treatment, compared with urban residents with non-agricultural hukou. In addition to China, the hukou system still exists in North Korea and Benin. Although Vietnam achieved the integration of registered residence (hukou bu) and identity cards on 1 July 2020, various restrictions derived from the household registration system still exist. With the aging of the population and the emergence of second-generation immigrant groups, the inequality of social services dependent on the household registration system has become more and more serious [12]. When analyzing the peri-urbanization of most Asian countries, Lee Kuan Yew pointed out that the focus should be on software facilities rather than hardware facilities [11]. Therefore, this study calls on the municipal authorities to reduce the living cost of the floating population in cities by improving the welfare benefits in housing, education, and medical treatment.

\subsection{Contributions, Limitations, and Future Research}

The study has three contributions: As for the method, SDM is used to consider the interaction amongst individuals. Academically, this research emphasizes the investigation on the impact of URIG on PPUR from the perspective of comparative economic benefits, different from the previous studies on the dynamic changes of PPUR from the perspective of farmers' income or urban residents' disposable income [20], thus contributing to the existing body of knowledge. In practice, the recommendations for reducing PPUR can be used for reference by those developing countries that adopt the household registration system. However, due to the difficulty of data acquisition, the research time span is too short to divide 2005-2014 into several periods in order to study whether the impact of URIG on PPUR is cyclical. In view of the fact that the phenomenon of population peri-urbanization still exists, finding a new measurement index of PPUR in the future is necessary to investigate the law of change over a longer period. 


\section{Conclusions}

Attracted by URIG, massive ATP has flown into cities and became a peri-urbanized population, which ultimately affects the development of people-oriented urbanization in China. Therefore, this study uses the spatial exploration analysis and SDM to investigate the impact of URIG and other control variables on PPUR from the national and regional levels, respectively. The research reveals that: (1) PPUR has spatial agglomeration and presents the characteristics of high values in Eastern and low values in Central and Western China. In addition, the PPUR of most provinces is rising, dominated by higher- and lower-degree PPUR. (2) At the national level, URIG promotes the increase of PPUR in the province, but inhibits the increase of PPUR in nearby areas. Except for HJ, other control variables all contribute to the PPUR of the province. (3) At the regional level, the URIG of Central and Western China contributes to the increase of PPUR, whereas that of Eastern China inhibits PPUR.

Regardless of URIG or other control variables, the essence of the impact on PPUR is that the allocation of various resources does not match the direction of population flow or that the finiteness of supply contradicts the infiniteness of demand. It is suggested that the relevant departments should coordinate the allocation of various resources with the trend of population mobility according to the size of the city. The abolition of the household registration system is not the ultimate goal. It is important to strive to achieve the equalization of software and hardware facilities and narrow the gap between urban and rural areas, whether in terms of income or various social welfare benefits. With the improvement of land-centered urbanization, we should also improve the quality of population urbanization, not only the quantity.

Author Contributions: Conceptualization, Z.M.; data curation, B.H.; formal analysis, Y.L. (Yong Liu); methodology, Y.L. (Yong Liu); writing—original draft preparation, B.H.; writing-review and editing, M.W. and Y.L. (Yingchao Lin); visualization, B.H.; funding acquisition, Z.M. and Y.L. (Yong Liu). All authors have read and agreed to the published version of the manuscript.

Funding: This research was funded by the National Social Science Foundation of China (18BJL034), the Fundamental Research Funds for the Central Universities of China (2018CDJSK03XK11, 2020CDJSK03YJ07) and the Chongqing Social Science Planning Project (2021YC020).

Data Availability Statement: The data that support the findings of this study are available from the corresponding author upon reasonable request.

Conflicts of Interest: The authors declare no conflict of interest.

\section{References}

1. Statistical Yearbook of China. Statistical Bulletin of National Economic and Social Development of the People's Republic of China in 2019; National Bureau of Statistics: 2020. Available online: http:/ /www.stats.gov.cn/tjsj/zxfb/202002/t20200228_1728913.html (accessed on 22 January 2021).

2. $\mathrm{Lu}, \mathrm{J} . ; \mathrm{Li}, \mathrm{B} . ; \mathrm{Li}, \mathrm{H}$. The influence of land finance and public service supply on peri-urbanization: Evidence from the counties in China. Habitat Int. 2019, 92, 13. [CrossRef]

3. Liu, X.; Cao, G.; Liu, T.; Liu, H. Semi-urbanization and evolving patterns of urbanization in China: Insights from the 2000 to 2010 national censuses. J. Geogr. Sci. 2016, 26, 1626-1642. [CrossRef]

4. Saunders, D. Arrival City; Pantheon Books: New York, NY, USA, 2010.

5. Chen, M.X.; Liu, W.D.; Lu, D.D.; Chen, H.; Ye, C. Progress of China's new-type urbanization construction since 2014: A preliminary assessment. Cities 2018, 78, 180-193. [CrossRef]

6. Chen, M.X.; Liu, W.D.; Lu, D.D. Challenges and the way forward in China's new-type urbanization. Land Use Policy 2016, 55, 334-339. [CrossRef]

7. Gottmann, J. Megalopolis or the urbanization of the northeastern Seaboard. Econ. Geogr. 1957, 33, 189. [CrossRef]

8. McGee, T.G. The Emergence of Desakota Regions in Asia: Expanding a Hypothesis; University of Hawail Press: Honolulu, HI, USA, 1991

9. Phillips, D.; Williams, K.; Smith, D. Literature Review on Peri-Urban Natural Resource Conceptualisation and Management Approaches; University of Nottingham: Nottingham, UK; University of Liverpoo: Liverpool, UK, 1999.

10. Webster, D.; Muller, L. Challenges of Peri-Urbanization in the Lower Yangtze Region: The Case of the Hangzhou-Ningbo Corridor; Asia/Pacific Research Center, Stanford University: Stanford, CA, USA, 2002. 
11. Webster, D. On the Edge: Shaping the Future of Peri-urban East Asia; Asia/Pacific Research Center, Stanford University: Stanford, CA, USA, 2002.

12. Webster, D.; Cai, J.; Muller, L.; Luo, B. Emerging Third Stage Peri-Urbanization Functional Specialization in the Hangzhou Peri-Urban Region; Asia-Pacific Research Center, Stanford University: Stanford, CA, USA, 2003.

13. Zhu, J.; Hu, T. Disordered Land Rent Competition in China's Peri-urbanization. Soc. Sci. Electron. Publ. 2008, 41, 1-28. [CrossRef]

14. Tian, L. Land use dynamics driven by rural industrialization and land finance in the pen-urban areas of China: "The examples of Jiangyin and Shunde". Land Use Policy 2015, 45, 117-127. [CrossRef]

15. Tian, L.; Ge, B.; Li, Y. Impacts of state-led and bottom-up urbanization on land use change in the peri-urban areas of Shanghai: Planned growth or uncontrolled sprawl? Cities 2017, 60, 476-486. [CrossRef]

16. Wang, C. A Study of Floating Rural People's “Semi-urbanization”. Sociol. Stud. 2006, 5, 107-122+244. (In Chinese)

17. Kontgis, C.; Schneider, A.; Fox, J.; Saksena, S.; Spencer, J.H.; Castrence, M. Monitoring peri-urbanization in the greater Ho Chi Minh City metropolitan area. Appl. Geogr. 2014, 53, 377-388. [CrossRef]

18. Hao, L. Cumulative Causation of Rural Migration and Initial Peri-Urbanization in China. Chin. Sociol. Rev. 2012, 44, 6-33. [CrossRef]

19. An, H.; Pi, Y. Research on peri-urbanization and population urbanization. Rev. Econ. Manag. 2013, 3, 5-10. (In Chinese)

20. Ji, M.; Zhong, M. Influence of Farmers' Income on Semi-Urbanization Rate-Based on SDM. J. Soc. Sci. 2018, 6, 39-51. (In Chinese)

21. Zhou, T.; Jiang, G.H.; Zhang, R.J.; Zheng, Q.Y.; Ma, W.Q.; Zhao, Q.L.; Li, Y.L. Addressing the rural in situ urbanization (RISU) in the Beijing-Tianjin-Hebei region: Spatio-temporal pattern and driving mechanism. Cities 2018, 75, 59-71. [CrossRef]

22. Chen, Y.; Luo, P.; Chang, T. Urbanization and the Urban-Rural Income Gap in China: A Continuous Wavelet Coherency Analysis. Sustainability 2020, 12, 8261. [CrossRef]

23. Tan, C. Introduction to Development Economics; Wuhan University Press: Wuhan, China, 2008. (In Chinese)

24. National Bureau of Statistics of China. Statistical Bulletin of National Economic and Social Development of the People's Republic of China in 2020; National Bureau of Statistics: Beijing, China, 2021. Available online: http://www.stats.gov.cn/tjsj/zxfb/202102/t2021022 7_1814154.html (accessed on 26 October 2021).

25. Han, J.; Miao, J.; Shi, Y.; Miao, Z. Can the semi-urbanization of population promote or inhibit the improvement of energy efficiency in China? Sustain. Prod. Consum. 2021, 26, 921-932. [CrossRef]

26. Zeng, C.; Zhang, A.; Xu, S. Urbanization and administrative restructuring: A case study on the Wuhan urban agglomeration. Habitat Int. 2016, 55, 46-57. [CrossRef]

27. Ye, C.H.; Sun, C.W.; Chen, L.T. New evidence for the impact of financial agglomeration on urbanization from a spatial econometrics analysis. J. Clean. Prod. 2018, 200, 65-73. [CrossRef]

28. Elhorst, J.P. Applied Spatial Econometrics: Raising the Bar. Spat. Econ. Anal. 2010, 5, 9-28. [CrossRef]

29. Elhorst, J.P. Matlab Software for Spatial Panels. Int. Reg. Sci. Rev. 2014, 37, 389-405. [CrossRef]

30. Lesage, J.; Pace, R.K. Introduction to Spatial Econometrics; Chapman and Hall/CRC: Boca Raton, FL, USA, 2009.

31. Wooldridge, J.M. Introduction to Econometrics; Renmin University Press of China: Beijing, China, 2010; p. 825. (In Chinese)

32. Lu, H.; Xie, H.; Yao, G. Impact of land fragmentation on marginal productivity of agricultural labor and non-agricultural labor supply: A case study of Jiangsu, China. Habitat Int. 2018, 83, 65-72. [CrossRef]

33. Wang, X.R.; Hui EC, M.; Sun, J.X. Population migration, urbanization and housing prices: Evidence from the cities in China. Habitat Int. 2017, 66, 49-56. [CrossRef]

34. Chen, C.; Zhao, M. The undermining of rural labor out-migration by household strategies in China's migrant-sending areas: The case of Nanyang, Henan Province. Cities 2017, 60, 446-453. [CrossRef]

35. Mohabir, N.; Jiang, Y.; Ma, R. Chinese floating migrants: Rural-urban migrant labourers' intentions to stay or return. Habitat Int. 2017, 60, 101-110. [CrossRef]

36. Wu, X.; Treiman, D.J. The household registration system and social stratification in China: 1955-1996. Demography 2004, 41, 363-384. [CrossRef] [PubMed] 